\title{
Universiteit
}

Leiden

The Netherlands

\section{Haplotypes of the EPCR gene, plasma SEPCR levels and the risk of deep venous thrombosis}

Willige, S.U. de; Marion, V. van; Rosendaal, F.R.; Vos, H.L.; Visser, M.C.H. de; Bertina, R.M.

\section{Citation}

Willige, S. U. de, Marion, V. van, Rosendaal, F. R., Vos, H. L., Visser, M. C. H. de, \& Bertina, R. M. (2004). Haplotypes of the EPCR gene, plasma sEPCR levels and the risk of deep venous thrombosis. Journal Of Thrombosis And Haemostasis, 2(8), 1305-1310. Retrieved from https://hdl.handle.net/1887/5084

Version: $\quad$ Not Applicable (or Unknown)

License:

Downloaded from: https://hdl.handle.net/1887/5084

Note: To cite this publication please use the final published version (if applicable). 


\title{
Haplotypes of the EPCR gene, plasma sEPCR levels and the risk of deep venous thrombosis
}

\author{
S. UITTE DE WILLIGE, ${ }^{*}$ V. VAN MARION, ${ }^{*}$ F. R. ROSENDAAL, ${ }^{*} \dagger$ H. L. VOS, ${ }^{*}$ M. C. H. DE VISSER * and \\ R. M. BERTINA* \\ ${ }^{*}$ Department of Haematology, Haemostasis and Thrombosis Research Center, $\uparrow$ Department of Clinical Epidemiology, Leiden University Medical \\ Center, Leiden, the Netherlands
}

To cite this article: Uitte de Willige S, Van Marion V, Rosendaal FR, Vos HL, De Visser MCH, Bertina RM. Haplotypes of the EPCR gene, plasma sEPCR levels and the risk of deep venous thrombosis. J Thromb Haemost 2004; 2 ; 1305-10.

\begin{abstract}
Summary. Background: Binding of protein C (PC) to the endothelial cell PC receptor (EPCR) stimulates PC activation by increasing the affinity of PC for the thrombin-thrombomodulin complex. A soluble form of this receptor (sEPCR) circulates in plasma and inhibits both PC activation and APC anticoagulant activity. Objectives: The aim of this study was to investigate whether variations in the EPCR gene or plasma sEPCR levels are risk factors for deep venous thrombosis (DVT). Patients/methods: In a large case-control study, the Leiden Thrombophilia Study (LETS), sEPCR levels were measured by ELISA. All subjects were genotyped for three haplotype-tagging SNPs, enabling us to detect all four common haplotypes of the EPCR gene. Results: The distribution of sEPCR levels in the control population was trimodal and was genetically controlled by haplotype 3 (H3). This haplotype explained $86.5 \%$ of the variation in sEPCR levels. Carriers of two $\mathrm{H} 3$ alleles had higher sEPCR levels $\left(439 \mathrm{ng} \mathrm{mL}^{-1}\right)$ than carriers of one $\mathrm{H} 3$ allele $\left(258 \mathrm{ng} \mathrm{mL}^{-1}\right)$, which had higher levels than non-H3 carriers $\left(94 \mathrm{ng} \mathrm{mL}^{-1}\right)$. Haplotype 4 was associated with a slightly increased risk (OR $=1.4,95 \%$ CI:1.0-2.2). The risk of subjects with sEPCR levels in the top quartile $\left(\geq 137 \mathrm{ng} \mathrm{mL}^{-1}\right.$ ) was increased compared to that of subjects in the first quartile $\left(<81 \mathrm{ng} \mathrm{mL}^{-1}\right)$, but since there was no doseresponse effect, it is most likely that low sEPCR levels reduce the risk of DVT. Conclusions: Our data do not suggest a strong association between EPCR haplotypes and thrombosis risk, but low sEPCR levels appear to reduce the risk of DVT.
\end{abstract}

Keywords: deep venous thrombosis, EPCR, haplotypes.

Correspondence: S Uitte de Willige, Haemostasis and Thrombosis Research Center, Department of Hematology, Leiden University Medical Center, Leiden, the Netherlands.

Tel.: + 3171 5266689; fax: + 3171 5266755; e-mail: suitte@ lumc.nl

Received 16 February 2004, accepted 13 April 2004

\section{Introduction}

The protein C pathway is a physiologically important mechanism for the regulation of the coagulation process. The pathway is triggered when thrombin binds to the endothelial cell surface receptor thrombomodulin. The thrombin-thrombomodulin complex activates protein $\mathrm{C}$. Activated protein $\mathrm{C}$ (APC), together with its cofactor protein S, limits the amplification and progression of the coagulation cascade by proteolytic inactivation of factors (F)Va and FVIIIa [1]. This process occurs on the negatively charged surface of activated platelets [2,3].

In 1994, an endothelial cell-specific protein C binding protein called endothelial cell protein $\mathrm{C}$ receptor (EPCR) was identified [4]. This receptor is a type I transmembrane protein that is almost exclusively expressed on the endothelium of large vessels [5]. Binding of protein $\mathrm{C}$ to EPCR stimulates protein $\mathrm{C}$ activation by increasing the affinity of protein $\mathrm{C}$ for the thrombin-thrombomodulin complex. EPCR can bind protein $\mathrm{C}$ and APC with similar affinities $[3,6]$.

EPCR is similar to molecules of the class I major histocompatibility complex, in particular the CD1-subfamily. In addition to the $\alpha 1$ and $\alpha 2$ extracellular domains, EPCR has a transmembrane domain and a very short cytoplasmic tail $[4,7]$. The EPCR gene spans approximately $6 \mathrm{~kb}$ and is located on chromosome 20q11.2. It consists of four exons. Exon 1 (amino acids 1-24) encodes the $5^{\prime}$ untranslated region (UTR), the signal peptide, and seven additional residues. Exons 2 (amino acids 24-108) and 3 (amino acids 108-201) encode most of the extracellular region of EPCR. Exon 4 (amino acids 201-238) encodes an additional 10 residues of the extracellular region of EPCR, the transmembrane domain, the cytoplasmic tail, and the $3^{\prime}$ UTR [8]. Several variations in the EPCR gene have been reported, among which a rare 23 bp insertion in exon 3 (position 6367), a polymorphism in intron 2 (C6333T), a polymorphism in exon 3 (C6622T) and a polymorphism in exon 4 (A6936G), which predicts an amino acid change (Ser219Gly) in the transmembrane region of the receptor (numbering according to GenBank accession number 
AF106202) [9,10]. Another polymorphism (G7014C) was identified in the $3^{\prime}$ UTR, of which the C-allele was reported to be associated with high levels of circulating APC and a reduced risk of deep venous thrombosis (DVT) [11,12].

Metalloprotease activity results in cleavage of the entire extracellular domain of EPCR [13]. The resulting soluble EPCR (sEPCR) retains its affinity for both protein $\mathrm{C}$ and APC, but now inhibits APC anticoagulant activity by blocking the interaction of protein $\mathrm{C}$ and APC with negatively charged surfaces [14], an interaction that is necessary for efficient inactivation of FVa and FVIIIa. In healthy individuals, plasma sEPCR circulates at a concentration of about $100 \mathrm{ng} \mathrm{mL}^{-1}$. sEPCR levels are increased in patients with systemic inflammatory diseases [15]. Decreased levels are observed during anticoagulant therapy [16]. Stearns-Kurosawa et al. reported a bimodal distribution of plasma sEPCR levels. Analyses of the plasma sEPCR levels of two healthy adult populations from France and Italy demonstrated that each was different from a Gaussian distribution [16,17].

The importance of the protein $\mathrm{C}$ pathway in the regulation of fibrin formation is emphasized by the elevated risk of DVT associated with protein $\mathrm{C}$ and protein $\mathrm{S}$ deficiencies and the FV Leiden mutation [18]. Therefore we hypothesized that variations in the EPCR gene or plasma SEPCR levels influence the risk of DVT. Mutations in the gene that lead to a loss of function could lead to decreased EPCR-activity on the membrane. This is expected to result in decreased APC formation, less inactivation of FVa and FVIIIa, more thrombin generation and an increased risk of thrombosis. On the other hand, overexpression of EPCR could result in a decreased thrombosis risk. Whether the level of sEPCR in plasma affects the risk of venous thrombosis is unclear, although, hypothetically, high as well as low plasma sEPCR levels may increase this risk. Elevated plasma sEPCR levels might be associated with a higher thrombotic risk, because plasma sEPCR inhibits both protein $\mathrm{C}$ activation and APC anticoagulant activity. Also high plasma sEPCR might result in a low residual EPCR level on the membrane and thus indicate reduced protein $\mathrm{C}$ activation. In contrast, low plasma sEPCR levels might also reflect low EPCR expression on the endothelium, leading to decreased APC formation, and thereby to an increased risk of thrombosis.

Recently, Saposnik et al. reported that a specific haplotype of the EPCR gene (A3) is associated with increased plasma sEPCR levels and is a candidate risk factor for venous thrombosis [19]. In our study, we identified the four most common haplotypes of the EPCR gene and studied their association with risk of venous thrombosis. The French study found three haplotypes (A1, A2 and A3) that are identical to our haplotypes $\mathrm{H} 1, \mathrm{H} 2$ and $\mathrm{H} 3$. We describe an additional haplotype (H4) that was not reported in their study. Furthermore, we studied various determinants of plasma SEPCR levels and investigated the association between plasma sEPCR levels and the development of a first DVT. For our study we used a large population-based case-control study on risk factors of venous thrombosis, the Leiden Thrombophilia Study (LETS).

\section{Subjects and methods}

\section{Study population}

The design of the Leiden Thrombophilia Study (LETS) has been described in detail previously [20,21]. In short, 474 consecutive patients with an objectively confirmed first episode of deep vein thrombosis and 474 sex- and age-matched controls were included. The patients were all younger than 70 years and were not known to have a malignant disorder. Acquaintances and partners of patients served as controls. The mean age for patients and controls was 45 years (range 15-69 for patients, 15-72 for controls). Both groups consist of 272 women and 202 men. Venous blood was collected into tubes containing 0.1 volume of $0.106 \mathrm{~mol} \mathrm{~L}^{-1}$ trisodium citrate. Plasma was prepared by centrifugation for $10 \mathrm{~min}$ at $2000 \times \boldsymbol{g}$ at room temperature and stored at $-70{ }^{\circ} \mathrm{C}$. High molecular weight DNA was isolated from leukocytes by standard methods and stored at $-20{ }^{\circ} \mathrm{C}$.

\section{SEPCR antigen measurement}

Plasma sEPCR levels were measured by enzyme linked immuno-sorbent assay (ELISA), according to the manufacturer's instructions. The Asserachrom ${ }^{\circledR}$ sEPCR ELISA kits were kindly provided by Diagnostica Stago (Asnières, France). The assay uses two different monoclonal antibodies against EPCR as catching and tagging antibody. Samples were diluted $1 / 26$ and assayed in duplicate.

\section{Genetic analysis}

In the EPCR gene, four common haplotypes are known (Fig. 1) [22]. We chose three htSNPs (haplotype-tagging Single Nucleotide Polymorphisms) to cover the four haplotypes (H1, $\mathrm{H} 2, \mathrm{H} 3$ and $\mathrm{H} 4)$ of the EPCR gene. An htSNP is a polymorphism of which the rare allele is specific to the haplotype. One haplotype $(\mathrm{H} 2)$ consists of the common alleles of all htSNPs. Genotyping was performed using the $5^{\prime}$ nuclease/TaqMan assay [23]. The polymerase chain reaction with fluorescent allele-specific oligonucleotide probes (Assayby-Design/Assay-on-Demand, Applied Biosystems, Foster City, CA, USA) was performed on a PTC-225 (Biozym, Hessisch Oldendorf, Germany) and fluorescence endpoint reading for allelic discrimination was done on an ABI 7900 HT (Applied Biosystems). For these analyses, 471 patient samples and 471 control samples were studied.

\section{Statistical analysis}

Odds ratios (OR) and $95 \%$ confidence intervals $(95 \% \mathrm{CI})$ were calculated as estimation of the risk of venous thrombosis for 


\begin{tabular}{|c|c|c|c|c|c|c|c|}
\hline & quenc & 离 & 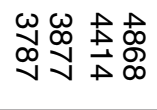 & 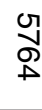 & $\stackrel{9}{\vec{A}}$ & & 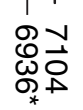 \\
\hline $\mathrm{H} 1$ & 0.39 & C & T A T C & C & G & C & A C \\
\hline $\mathrm{H} 2$ & 0.43 & C & 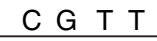 & $\mathrm{T}$ & G & $T$ & $A G$ \\
\hline $\mathrm{H} 3$ & 0.13 & G & $C G T T$ & $T$ & G & $\mathrm{T}$ & $G \mathrm{G}$ \\
\hline $\mathrm{H} 4$ & 0.05 & C & $C G C T$ & $T$ & & $T$ & A G \\
\hline
\end{tabular}

Fig. 1 The four haplotypes of the EPCR gene (numbering according to GeneBank accession number AF106202). The polymorphisms with an asterisk are the selected htSNPs.

carriers of the rare allele of each htSNP compared to carriers of the common allele. Whether variations in plasma sEPCR levels are a risk factor for venous thrombosis was investigated by calculating ORs and $95 \%$ CIs of the quartiles of plasma sEPCR levels measured in the control subjects. Putative determinants of plasma sEPCR levels were investigated in the control subjects only, who reflect the general population. The measurements of FII activity [24], FV:Ag [25], FVII activity [26], FVIII activity [27], FIX activity [28], FX Ag [29], FXI:Ag [30], FXII activity [31], FXIII A and B subunit Ag [32], protein C activity [33], total and free protein $\mathrm{S} \mathrm{Ag}$ [33], antithrombin activity [33] and fibrinogen levels [26] have been described before. To investigate the relationship between sEPCR levels and oral contraceptive use, an additional selection was made, as described before [34,35]. Premenopausal control women aged 15-49 $(n=153)$ were selected after exclusion of women who were pregnant $(n=10)$, within 30 days postpartum $(n=$ $14)$, with a recent miscarriage $(n=2)$ or who had used only depot contraceptives $(n=3)$ at the index date. Because of the trimodal distribution of the plasma SEPCR levels, we used the Mann-Whitney non-parametric test for these analyses. To investigate the association between htSNP A6936G (H3) and plasma sEPCR levels, mean levels with $95 \%$ CIs were calculated. Forty-eight of the patients and one of the control subjects were on oral anticoagulant therapy. Use of oral anticoagulation reduced sEPCR levels, confirming previous results [16]. The mean plasma level in the 48 patients using oral anticoagulation was much lower $\left(86.6 \mathrm{ng} \mathrm{mL}^{-1}\right)$ than the mean levels in 426 non-users $\left(147.7 \mathrm{ng} \mathrm{mL}^{-1}\right)$. Therefore, oral anticoagulation users were excluded from analyses concerning sEPCR levels. For these analyses, we studied 426 patients and 472 control subjects. Since three DNA samples were missing, we could use 469 control subjects for the combined analyses of sEPCR levels with genotype.

\section{Results}

\section{EPCR haplotypes and the risk of venous thrombosis}

The genotypes for all three htSNPs could be determined in 471 patients and 471 control subjects. None of the subjects carried more than two htSNPs, suggesting an absence of recombination in the EPCR gene. The distribution of the genotypes among control subjects was as expected for a population in Hardy-Weinberg equilibrium.

In Table 1, the venous thrombosis risk associated with each haplotype in the EPCR gene is shown. Carriers of one or two $\mathrm{H} 1$ alleles had a slightly decreased risk $(\mathrm{OR}=0.8,95 \% \mathrm{CI}$ : $0.6-1.1) . \mathrm{H} 2$ and $\mathrm{H} 3$ were not associated with the risk of venous thrombosis. The group of individuals with either one or two $\mathrm{H} 4$ alleles had a weakly increased risk compared with individuals without a $\mathrm{H} 4$ allele $(\mathrm{OR}=1.4,95 \% \mathrm{CI}$ : $1.0-2.2)$.

The risk associated with $\mathrm{H} 4$ was not materially affected by age, as both the younger and older subgroup showed a very similar risk $(<45$ : $\mathrm{OR}=1.5,95 \% \mathrm{CI}: 0.9-2.7 ; \geq 45$ : OR $=$ 1.4, 95\%CI: 0.8-2.4). The risks associated with the other haplotypes were not affected by age either. When the risk of developing venous thrombosis was assessed for men and

Table 1 Thrombosis risk of the four most common haplotypes of the EPCR gene

\begin{tabular}{lcccc}
\hline $\begin{array}{l}\text { Haplotype } \\
\text { (htSNP) }\end{array}$ & $\begin{array}{c}\text { Patients }(\%) \\
n=471\end{array}$ & $\begin{array}{c}\text { Controls }(\%) \\
n=471\end{array}$ & OR & $95 \% \mathrm{CI}$ \\
\hline H1 (T6333C) & & & & \\
HxHx & $192(40.8)$ & $171(36.3)$ & $1^{*}$ & \\
H1Hx & $215(45.6)$ & $231(49.0)$ & 0.8 & $0.6-1.1$ \\
H1H1 & $64(13.6)$ & $69(14.6)$ & 0.8 & $0.6-1.2$ \\
H1Hx/H1H1 & $279(59.2)$ & $300(63.7)$ & 0.8 & $0.6-1.1$ \\
Frequency H1 & 36.4 & 39.2 & & \\
H2 (all common) & & & & \\
HxHx & $157(33.3)$ & $152(32.3)$ & $1^{*}$ & \\
H2Hx & $233(49.5)$ & $234(49.7)$ & 1.0 & $0.7-1.3$ \\
H2H2 & $81(17.2)$ & $85(18.0)$ & 0.9 & $0.6-1.4$ \\
H2Hx/H2H2 & $314(66.7)$ & $319(67.7)$ & 1.0 & $0.7-1.3$ \\
Frequency H2 & 41.9 & 42.9 & & \\
H3 (A6936G) & & & & \\
HxHx & $345(73.2)$ & $361(76.6)$ & $1^{*}$ & \\
H3Hx & $116(24.6)$ & $100(21.2)$ & 1.2 & $0.9-1.7$ \\
H3H3 & $10(2.1)$ & $10(2.1)$ & 1.1 & $0.4-2.6$ \\
H3Hx/H3H3 & $126(26.8)$ & $110(23.4)$ & 1.2 & $0.9-1.6$ \\
Frequency H3 & 14.4 & 12.7 & & \\
H4 (G6147A) & & & & \\
HxHx & $406(86.2)$ & $424(90.0)$ & $1^{*}$ & \\
H4Hx & $62(13.2)$ & $45(9.6)$ & 1.4 & $1.0-2.2$ \\
H4H4 & $3(0.6)$ & $2(0.4)$ & 1.6 & $0.3-9.4$ \\
H4Hx/H4H4 & $65(13.8)$ & $47(10.0)$ & 1.4 & $1.0-2.2$ \\
Frequency H4 & 7.2 & 5.2 & & \\
\hline Reference Categra & & & \\
\hline
\end{tabular}

*Reference Category; Hx: all haplotypes but the one given. 


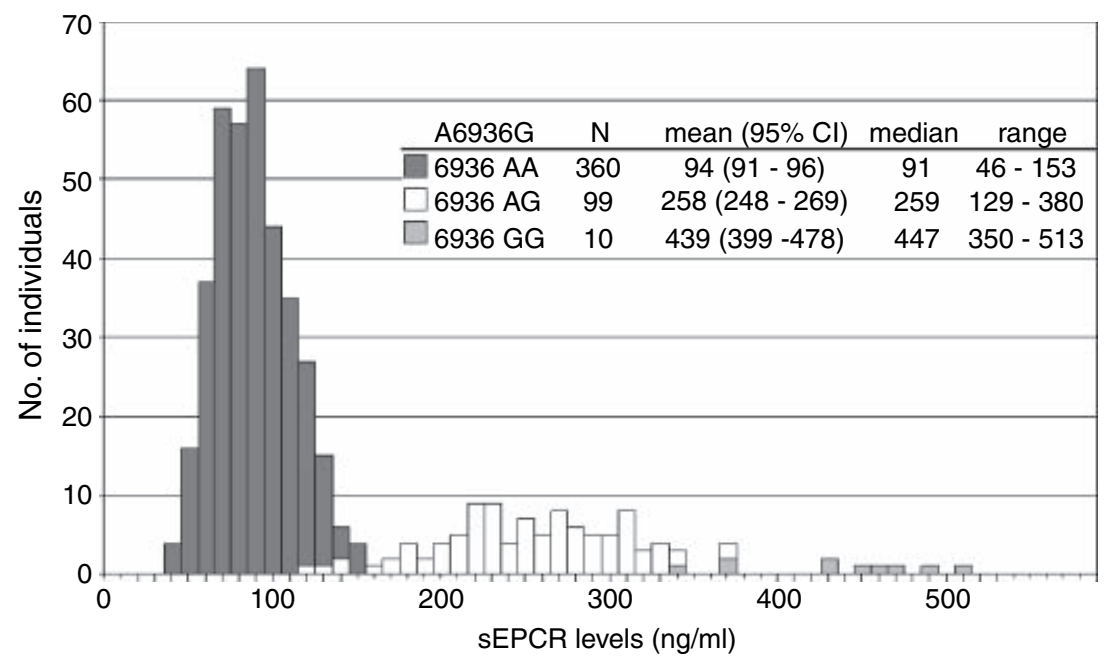

Fig. 2 Distribution of sEPCR levels in control subjects, by genotype for A6936G (H3) $(n=469)$

women separately, we found that the risk associated with $\mathrm{H} 4$ was slightly higher in women $(\mathrm{OR}=1.6,95 \% \mathrm{CI}: 0.9-3.0)$ than in men $(\mathrm{OR}=1.3,95 \%$ CI: $0.8-2.3)$. The ORs of the other haplotypes were not affected by sex.

A total number of 116 patients and 25 control subjects carried the FV Leiden mutation and/or the prothrombin 20210 A allele. Exclusion of these individuals did not change the risks associated with the four haplotypes.

\section{Distribution and determinants of SEPCR levels}

Figure 2 shows the distribution of sEPCR levels in the group of healthy controls. The distribution seems to be trimodal. We investigated the effect of age, sex, oral contraceptive use and haplotype on this distribution. sEPCR levels were influenced most by the EPCR haplotype. The G allele of the htSNP specific for H3 (A6936G) was associated with increased plasma sEPCR levels, as was also observed by Saposnik et al. [19]. Carriers of two $6936 \mathrm{G}$ alleles had higher sEPCR levels than GA heterozygotes, which had higher levels than AA carriers. By correlation analysis we found that as much as $86.5 \%$ of the variation in plasma SEPCR levels could be explained by this polymorphism. The trimodal distribution of sEPCR levels combined with information on the A6936G genotype in the group of healthy controls $(n=469)$ is shown in Fig. 2. The other haplotypes did not show any effect on plasma sEPCR levels.

The effect of other putative determinants of plasma sEPCR levels is shown in Table 2. Men had higher plasma sEPCR levels than women and individuals older than 45 years had higher sEPCR levels than individuals younger than 45 years. The use of oral contraceptives lowered plasma sEPCR levels. Because sEPCR has the same affinity for both protein $\mathrm{C}$ and APC, we also assessed whether there was an association between plasma sEPCR and protein $\mathrm{C}$ levels. We found that individuals with protein $\mathrm{C}$ levels $<101 \mathrm{U} \mathrm{dL}^{-1}$ had lower sEPCR levels than those with protein $\mathrm{C}$ levels $\geq 101 \mathrm{U} \mathrm{dL}^{-1}$
Table 2 Determinants of sEPCR levels in healthy controls

\begin{tabular}{lcccc}
\hline Determinants & $n$ & Median & Range & $P^{*}$ \\
\hline Sex & & & & \\
$\quad$ Male & 200 & 111 & $49-513$ & \\
$\quad$ Female & 272 & 92 & $46-500$ & $<0.0001$ \\
Age & & & & \\
$\quad<45$ & 239 & 96 & $48-513$ & \\
$\quad \geq 45$ & 233 & 104 & $46-479$ & 0.04 \\
Use of oral contraceptives & & & \\
$\quad$ Yes & 54 & 79 & $48-513$ & \\
$\quad$ No & 99 & 91 & $46-479$ & 0.04 \\
Protein C levels & & & & \\
$\quad<101$ & 232 & 96 & $48-513$ & \\
$\quad \geq 101$ & 232 & 111 & $46-500$ & $<0.0001$ \\
\hline
\end{tabular}

*P-values obtained after Mann-Whitney test.

(Table 2). Protein $\mathrm{C}$ levels (expressed in $\mathrm{U} \mathrm{dL}^{-1}$ [36]) and sEPCR levels (expressed in $\mathrm{ng} \mathrm{mL}^{-1}$ ) were positively correlated, with a regression coefficient of 1.81 (95\% CI: 1.4-2.2).

Other variables such as smoking, body mass index, C-reactive protein, $\mathrm{ABO}$ blood group, levels of other clotting factors (FII, FV, FVII, FVIII, FIX, FX, FXI, FXII, FXIIIA subunit, FXIIIB subunit, fibrinogen, protein $\mathrm{S}$, antithrombin) and D-Dimer had no influence on plasma sEPCR levels.

Because of the great influence of $\mathrm{H} 3$ on sEPCR levels, we also investigated the above mentioned determinants in the subgroup of 6936 A homozygotes. In this group we found similar results.

\section{SEPCR levels and the risk of venous thrombosis}

The median plasma sEPCR level in the 426 patients not using oral anticoagulation was slightly higher $\left(104 \mathrm{ng} \mathrm{mL}^{-1}\right)$ than the median in the 472 control subjects $\left(101 \mathrm{ng} \mathrm{mL}^{-1}\right)$. To assess whether levels of sEPCR were associated with an increased risk of DVT, we divided the sEPCR levels into quartiles, as measured in the healthy control group. As shown in Table 3, the risk of subjects with plasma sEPCR levels in the top quartile 
Table 3 The risk of sEPCR levels in quartiles

\begin{tabular}{lrlll}
\hline $\begin{array}{l}\text { sEPCR } \\
(\mathrm{ng} / \mathrm{mL})\end{array}$ & $\begin{array}{l}\text { Patients }(\%) \\
n=426\end{array}$ & $\begin{array}{l}\text { Controls }(\%) \\
n=472\end{array}$ & OR & $95 \% \mathrm{CI}$ \\
\hline$<81$ & $74(17.4)$ & $122(25.8)$ & $1^{*}$ & \\
$81-101$ & $122(28.6)$ & $114(24.2)$ & 1.8 & $1.2-2.6$ \\
$101-137$ & $95(22.3)$ & $118(25.0)$ & 1.3 & $0.9-2.0$ \\
$\geq 137$ & $135(31.7)$ & $118(25.0)$ & 1.9 & $1.3-2.8$ \\
\hline
\end{tabular}

*Reference category.

( $\geq 137 \mathrm{ng} \mathrm{mL}^{-1}$ ) was increased compared to that of subjects in the first quartile $\left(<81 \mathrm{ng} \mathrm{mL}^{-1}\right)$. Taking the first quartile as a reference group, the second and third quartiles also gave increased ORs, but there was no evidence of a dose-response relationship. Adjustment for age and sex did not change the ORs.

\section{Discussion}

In this study we investigated the association of the four most common haplotypes of the EPCR gene with plasma SEPCR levels and the risk of DVT. We genotyped all subjects of the LETS for these four haplotypes and measured the plasma sEPCR levels.

The four most common haplotypes of the EPCR gene were all present at frequencies above $5 \%$ and none was clearly associated with an increased risk of DVT. España et al. reported that CC homozygotes of a polymorphism (G7014C), of which the $\mathrm{C}$-allele is specific for $\mathrm{H} 1$, had a 2.6-fold reduced risk of DVT in a study of 184 cases and 160 controls [11]. However, in the study of Galligan et al. the same polymorphism was not associated with the risk of venous thrombosis in 389 cases and 262 controls [37]. In our study, the risk associated with $\mathrm{H} 1$ was essentially the same as for the other haplotypes, although a reduced risk could not be excluded. Only H4, which was not reported in a recent French study [19] was weakly associated with thrombotic risk. In contrast to the French study, we found no association of $\mathrm{H} 3$ with the risk of DVT. We found a slightly higher frequency of $\mathrm{H} 3$ than the French study, especially in the controls. After exclusion of subjects with the FV Leiden mutation and the prothrombin 20210 A allele the risks associated with the four haplotypes did not change.

To determine whether variations in plasma SEPCR levels influenced the risk of DVT, the effects were investigated using various cut-off levels. We found that when compared with the first quartile of plasma sEPCR levels $\left(<81 \mathrm{ng} \mathrm{mL}^{-1}\right)$ the top quartile $\left(\geq 137 \mathrm{ng} \mathrm{mL}^{-1}\right)$ was associated with an increased risk of venous thrombosis. The risk of the 2 nd and 3 rd quartiles was also increased relative to that of the first quartile. However, the absence of a gradient of risk over the levels of sEPCR renders it implausible that the observed increased risk associated with sEPCR levels $\geq 81 \mathrm{ng} \mathrm{mL}^{-1}$ is a true effect. This would also explain why the $\mathrm{H} 3$ haplotype, which is associated with strongly elevated sEPCR levels, did not increase the risk of thrombosis. When we express the results of these analyses in terms of risk reduction, we found that plasma sEPCR levels below
$81 \mathrm{ng} \mathrm{mL} \mathrm{m}^{-1}$ were associated with a decrease in risk $(\mathrm{OR}=$ $0.6,95 \%$ CI: $0.4-0.8$ ) when compared to sEPCR levels above this value. Low plasma sEPCR levels could be the result of an ineffective or reduced metalloproteolytic cleavage, which keeps most of the membrane-bound EPCR available for activating protein C. It is also possible that low sEPCR levels reflect a state of low thrombin generation (thrombin has been reported to stimulate SEPCR release in cultured endothelial cells [38]).

In the healthy control subjects, the distribution of the sEPCR levels was trimodal. High levels of sEPCR were associated with a specific haplotype $(\mathrm{H} 3)$ as reported previously [19]. This haplotype explains $86.5 \%$ of all variation in plasma sEPCR levels of the control subjects in our study. The nucleotide change in the polymorphism specific for $\mathrm{H} 3$ (A6936G) results in a Ser to Gly amino acid change in the transmembrane region of the receptor and predicts a conformational change of the molecule. An explanation for the high sEPCR levels associated with this haplotype could be that replacement of Ser219 by Gly introduces a conformational change in the molecule, which renders the molecule more susceptible to metalloproteolytic cleavage. Alternatively, it might affect the distribution of EPCR between the membrane and intracellular sites. It is also possible that the $6936 \mathrm{G}$ is linked to another variation in $\mathrm{H} 3$ which is functional, although there are presently no obvious candidates (see Fig. 1).

Of the putative determinants of sEPCR levels that were investigated, protein $\mathrm{C}$ had the largest influence on sEPCR levels. We found a positive association between protein $\mathrm{C}$ levels and SEPCR levels. It is possible that in plasma SEPCR partially circulates in complex with protein $\mathrm{C}$ and that the half-life of these complexes is higher than that of free sEPCR.

In conclusion, we showed that none of the haplotypes of the EPCR gene is associated with a strong thrombosis risk, but low sEPCR levels appear to reduce the risk of DVT.

\section{Acknowledgments}

This study was financially supported by grant 912-02-036 from the Netherlands Organization for Scientific Research (NWO). The LETS study was supported by grant 89-063 from the Netherlands Heart Foundation.

\section{References}

1 Dahlbäck B. Blood coagulation. Lancet 2000; 355: 1627-32.

2 Esmon CT, Ding W, Yasuhiro K, Gu JM, Ferrell G, Regan LM, Stearns-Kurosawa DJ, Kurosawa S, Mather T, Laszik Z, Esmon NL. The protein C pathway: new insights. Thromb Haemost 1997; 78: $70-4$.

3 Esmon CT, Xu J, Gu JM, Qu D, Laszik Z, Ferrell G, StearnsKurosawa DJ, Kurosawa S, Taylor FB Jr, Esmon NL. Endothelial protein C receptor. Thromb Haemost 1999; 82: 251-8.

4 Fukudome K, Esmon CT. Identification, cloning, and regulation of a novel endothelial cell protein $\mathrm{C} /$ activated protein $\mathrm{C}$ receptor. $J$ Biol Chem 1994; 269: 26486-91.

5 Laszik Z, Mitro A, Taylor FB Jr, Ferrell G, Esmon CT. Human protein $\mathrm{C}$ receptor is present primarily on endothelium of large blood 
vessels: implications for the control of the protein C pathway. Circulation 1997; 96: 3633-40.

6 Stearns-Kurosawa DJ, Kurosawa S, Mollica JS, Ferrell GL, Esmon $\mathrm{CT}$. The endothelial cell protein $\mathrm{C}$ receptor augments protein $\mathrm{C}$ activation by the thrombin-thrombomodulin complex. Proc Natl Acad Sci USA 1996; 93: 10212-6.

7 Fukudome KYeX, Tsuneyoshi N, Tokunaga O, Sugawara K, Mizokami H, Kimoto M. Activation mechanism of anticoagulant protein $\mathrm{C}$ in large blood vessels involving the endothelial cell protein $\mathrm{C}$ receptor. J Exp Med 1998; 187: 1029-35.

8 Simmonds RE, Lane DA. Structural and functional implications of the intron/exon organization of the human endothelial cell protein $\mathrm{C} /$ activated protein $\mathrm{C}$ receptor (EPCR) gene: comparison with the structure of CD1/major histocompatibility complex alphal and alpha2 domains. Blood 1999; 94: 632-41.

9 Merati G, Biguzzi E, Oganesyan N, Fetiveau R, Qu D, Bucciarelli P, Stearns-Kurosawa DJ, Mannucci PM, Esmon CT, Faioni EM. A 23bp insertion in the endothelial protein $\mathrm{C}$ receptor (EPCR) gene in patients with myocardial infarction and deep vein thrombosis. Thromb Haemost 1999; 82: 1596.

10 Biguzzi E, Merati G, Liaw PC, Bucciarelli P, Oganesyan N, Qu D, Gu JM, Fetiveau R, Esmon CT, Mannucci PM, Faioni EM. A 23bp insertion in the endothelial protein $\mathrm{C}$ receptor (EPCR) gene impairs EPCR function. Thromb Haemost 2001; 86: 945-8.

11 España F, Medina P, Mira Y, Estelles A, Vaya A, Villa P, Royo M, Aznar J, Bertina RM. A new polymorphism in the $3^{\prime} \mathrm{UTR}$ region of the endothelial protein $C$ receptor associated with increased levels of circulating activated protein $\mathrm{c}$ and decreased risk of venous thrombosis. Thromb Haemost 2001; 1 (Suppl. 1): Abstract OC885.

12 España F, Medina P, Navarro S, Estelles A, Aznar J. Inherited abnormalities in the protein $\mathrm{C}$ activation pathway. Pathophysiol Haemost Thromb 2002; 32: 241-4.

$13 \mathrm{Xu} \mathrm{J}, \mathrm{Qu}$ D, Esmon NL, Esmon CT. Metalloproteolytic release of endothelial cell protein C receptor. J Biol Chem 2000; 275: 6038-44.

14 Liaw PC, Neuenschwander PF, Smirnov MD, Esmon CT. Mechanisms by which soluble endothelial cell protein $\mathrm{C}$ receptor modulates protein C and activated protein C function. $J$ Biol Chem 2000; 275 : $5447-52$.

15 Kurosawa S, Stearns-Kurosawa DJ, Carson CW, D'Angelo A, Della VP, Esmon CT. Plasma levels of endothelial cell protein C receptor are elevated in patients with sepsis and systemic lupus erythematosus: lack of correlation with thrombomodulin suggests involvement of different pathological processes. Blood 1998; 91: 725-7.

16 Stearns-Kurosawa DJ, Swindle K, D'Angelo A, Della VP, Fattorini A, Caron N, Grimaux M, Woodhams B, Kurosawa S. Plasma levels of endothelial protein $\mathrm{C}$ receptor respond to anticoagulant treatment. Blood 2002; 99: 526-30.

17 Stearns-Kurosawa DJ, Burgin C, Parker D, Comp P, Kurosawa S. Bimodal distribution of soluble endothelial protein $\mathrm{C}$ receptor levels in healthy populations. J Thromb Haemost 2003; 1: 855-6.

18 Bertina RM. Factor V Leiden and other coagulation factor mutations affecting thrombotic risk. Clin Chem 1997; 43: 1678-83.

19 Saposnik B, Reny JL, Gaussem P, Emmerich J, Aiach M, Gandrille S. A haplotype of the EPCR gene is associated with increased plasma levels of sEPCR and is a candidate risk factor for thrombosis. Blood 2003; 103: 1311-8.

20 Koster T, Rosendaal FR, de Ronde H, Briët E, Vandenbroucke JP, Bertina RM. Venous thrombosis due to poor anticoagulant response to activated protein C. Leiden Thrombophilia Study. Lancet 1993; 342: $1503-6$.

21 van der Meer FJ, Koster T, Vandenbroucke JP, Briët E, Rosendaal FR. The Leiden Thrombophilia Study (LETS). Thromb Haemost 1997; 78: 631-5.
22 Nickerson D. Seattle SNPs. NHLBI Program for Genomic Applications, UW-FHCRC, Seattle, WA. http://pga.gs.washington. edu2003.

23 Livak KJ. Allelic discrimination using fluorogenic probes and the $5^{\prime}$ nuclease assay. Genet Anal 1999; 14: 143-9.

24 Poort SR, Rosendaal FR, Reitsma PH, Bertina RM. A common genetic variation in the $3^{\prime}$-untranslated region of the prothrombin gene is associated with elevated plasma prothrombin levels and an increase in venous thrombosis. Blood 1996; 88: 3698-703.

25 Kamphuisen PW, Rosendaal FR, Eikenboom JC, Bos R, Bertina RM. Factor V antigen levels and venous thrombosis: risk profile, interaction with factor V leiden, and relation with factor VIII antigen levels. Arterioscler Thromb Vasc Biol 2000; 20: 1382-6.

26 Koster T, Rosendaal FR, Reitsma PH, van der Velden PA, Briët E, Vandenbroucke JP. Factor VII and fibrinogen levels as risk factors for venous thrombosis. A case-control study of plasma levels and DNA polymorphisms - the Leiden Thrombophilia Study (LETS). Thromb Haemost 1994; 71: 719-22.

27 Koster T, Blann AD, Briët E, Vandenbroucke JP, Rosendaal FR. Role of clotting factor VIII in effect of von Willebrand factor on occurrence of deep-vein thrombosis. Lancet 1995; 345: 152-5.

28 van Hylckama Vlieg A, van der Linden I, Bertina RM, Rosendaal FR. High levels of factor IX increase the risk of venous thrombosis. Blood 2000; 95: 3678-82.

29 de Visser MCH, Poort SR, Vos HL, Rosendaal FR, Bertina RM. Factor X levels, polymorphisms in the promoter region of factor $\mathrm{X}$, and the risk of venous thrombosis. Thromb Haemost 2001; 85: 1011-7.

30 Meijers JC, Tekelenburg WL, Bouma BN, Bertina RM, Rosendaal FR. High levels of coagulation factor XI as a risk factor for venous thrombosis. $N$ Engl J Med 2000; 342: 696-701.

31 Koster T, Rosendaal FR, Briët E, Vandenbroucke JP. John Hageman's factor and deep-vein thrombosis: Leiden thrombophilia Study. Br J Haematol 1994; 87: 422-4.

32 van Hylckama Vlieg A, Komanasin N, Ariëns RA, Poort SR, Grant PJ, Bertina RM, Rosendaal FR. Factor XIII Val34Leu polymorphism, factor XIII antigen levels and activity and the risk of deep venous thrombosis. Br J Haematol 2002; 119: 169-75.

33 Koster T, Rosendaal FR, Briët E, van der Meer FJ, Colly LP, Trienekens PH, Poort SR, Reitsma PH, Vandenbroucke JP. Protein C deficiency in a controlled series of unselected outpatients: an infrequent but clear risk factor for venous thrombosis (Leiden Thrombophilia Study). Blood 1995; 85: 2756-61.

34 Vandenbroucke JP, Koster T, Briët E, Reitsma PH, Bertina RM, Rosendaal FR. Increased risk of venous thrombosis in oral-contraceptive users who are carriers of factor V Leiden mutation. Lancet 1994; 344: 1453-7.

35 Bloemenkamp KW, Rosendaal FR, Helmerhorst FM, Koster T, Bertina RM, Vandenbroucke JP. Hemostatic effects of oral contraceptives in women who developed deep-vein thrombosis while using oral contraceptives. Thromb Haemost 1998; 80: 382-7.

36 de Visser MCH, Rosendaal FR, Bertina RM. A reduced sensitivity for activated protein $\mathrm{C}$ in the absence of factor $\mathrm{V}$ Leiden increases the risk of venous thrombosis. Blood 1999; 93: 1271-6.

37 Galligan L, Powell C, Livingstone W, Mynett-Johnston L, Smith OP. The $\mathrm{G} 7763 \mathrm{C}$ endothelial protein $\mathrm{C}$ receptor (EPCR) gene mutation. prevalence and association with DVT in the Irish population. Thromb Haemost 2002; 88: 163-5.

38 Gu JM, Katsuura Y, Ferrell GL, Grammas P, Esmon CT. Endotoxin and thrombin elevate rodent endothelial cell protein $\mathrm{C}$ receptor mRNA levels and increase receptor shedding in vivo. Blood 2000; 95: 1687-93. 